\title{
A Trump Effect on the EU's Popularity? The U.S. Presidential Election as a Natural Experiment
}

\author{
Lara Minkus, Emanuel Deutschmann, and Jan Delhey
}

\begin{abstract}
Did the election of Donald Trump affect the popularity of the European Union (EU) in Europe? Theoretically, both a positive rally effect (due to a perceived external threat) and a negative domino effect (due to resignation among Europhiles and/or reinforcement among europhobe nationalists) are plausible. We treat Trump's unexpected victory as an external shock and use a Eurobarometer survey that was conducted in all EU-28 member states four days prior to (control group) and six days after the election (treatment group) as source material for a natural experiment. The analysis reveals that the election of Trump caused a significant increase in the EU's popularity in Europe immediately after the election. This "Trump effect" is considerable in size, roughly equivalent to three years of education. Gains in popularity were particularly high among respondents who perceived their country as economically struggling and, surprisingly, among the political right, suggesting that Trump's victory broadened and ideologically diversified the EU's base of support.
\end{abstract}

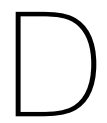

uring the night between November 8 and 9, 2016, the election of Donald Trump as the forty-fifth president of the United States took pollsters by surprise. The New York Times' prediction, for instance- - followed by a global audience on the newspaper's website during election night—made an exorbitant swing: in a matter of hours, Trump's "chance of winning the presidency" rose from a mere $15 \%$ at $1: 10 \mathrm{UCT}$ to $95 \%$ at 3:56 UCT, while Hillary Clinton's chance dropped accordingly (figure 1A). And the New York Times' miscalculation was no exception: 14 out of 15 national polls conducted in the United States during the first week of November

A list of permanent links to Supplementary Materials provided by the authors precedes the References section.

Lara Minkus is a PhD Fellow at the Bremen International Graduate School of Social Sciences and a research fellow at the SOCIUM Research Center on Inequality and Social Policy (lminkus@uni-bremen.de). She holds a B.A. in Sociology from the University of Mannheim and an M.A. in Sociological and Economic Studies from the University of Hamburg. Her research interests include public opinion, political sociology, social inequality, and gender. Emanuel Deutschmann is a Postdoctoral Researcher at the European University Institute's Robert Schuman Centre for Advanced Studies (emanuel.deutschmann@eui. eu). He works on social networks, transnational mobility and communication, regional integration, and globalization. His most recent article is "The Power of Contact: Europe as a Network of Transnational Attachment," published in the European Journal of Political Research. Jan Delhey holds the Chair of Macrosociology at Otto-von-Guericke University Magdeburg (jan.delhey@ ovgu.de). Building upon a strong background in quantitative comparative sociology, he engages in research on individual and collective quality-of-life, as well as on sociological aspects of European integration and globalization. He has published widely on issues of trust, social cohesion, subjective well-being, inequality, and Europeanization in leading journals, including American Sociological Review, European Sociological Review, and Social Indicators Research.

This research is part of the project "Cross-border Interactions and Transnational Identities," which is supported by the German Research Foundation (DFG) within the framework of the DFG research unit FOR-1539 Horizontal Europeanization. For more information, see http://www. horizontal-europeanization.eulen. We are grateful to the participants of the research colloquium at the Chair of Macrosociology at Otto von Guericke University Magdeburg for useful comments and suggestions and to Cheryl Abundo for important advice. We would also like to thank five anonymous reviewers at Perspectives on Politics for their invaluable feedback that strongly improved the article. 
predicted a Clinton victory. ${ }^{1}$ The public, too, appeared surprised by the Democratic candidate's defeat. Immediately after the unexpected election outcome, Internet searches for "Donald Trump" skyrocketed, as Google Trends data reveal (figure 1B).

To many European observers, Trump's victory came not only as a surprise ${ }^{2}$ but also as a shock. Apart from a general dismay vis-à-vis Trump's apparent misogynism, ${ }^{3}$ anapirism, ${ }^{4}$ xenophobia, ${ }^{5}$ and Islamophobia, ${ }^{6}$ many Europeans suspected that his election would affect transatlantic relations and prospects of European integration. Such concerns were fueled by Trump's nationalist credo "America first," condemnatory statements about NATO and TTIP, and consentient comments regarding the looming partial breakup of the $\mathrm{EU}$ in the wake of Brexit. ${ }^{7}$ A need to reinvent Europe's role in the world was one fear; a reinforcement of right-wing populist parties in Europe and according consequences for upcoming national elections was another. It has been argued that "dramatic and extraordinary real-world events have the power to impact on public opinion and to cause shift in public attitudes." 8 Trump's election

\section{Figure 1}

\section{The election of Donald Trump as an "external shock"}
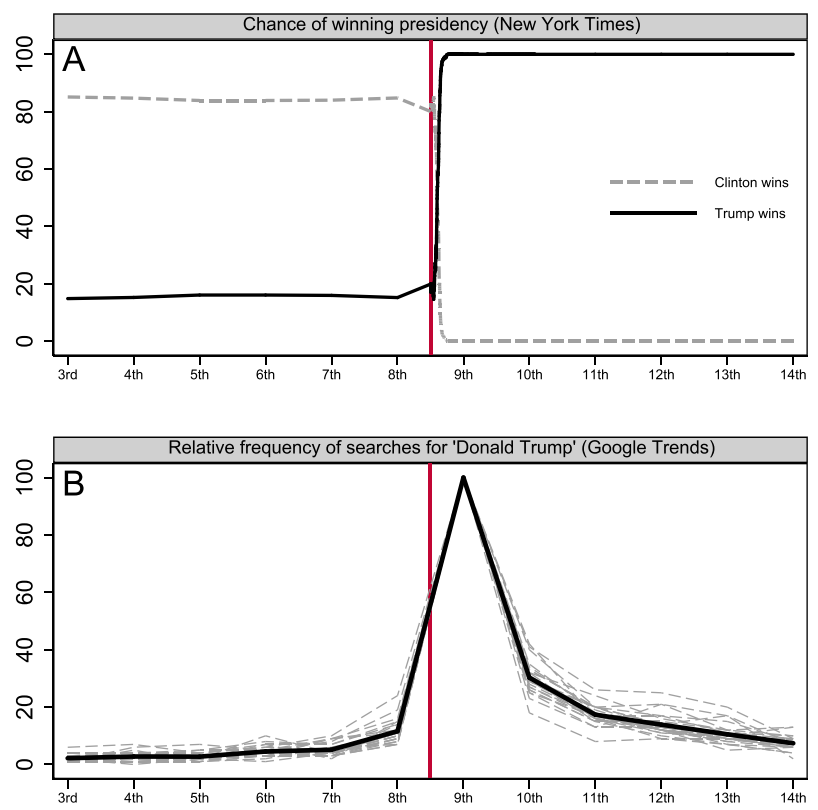

Figure 1A combines scraped data from two New York Times websites (nyti.ms/2miH2qZ and nyti.ms/2gOIYTY, last accessed 8/ 8/2017);

Figure 1B is based on Google Trends (trends.google.com, last accessed 10/10/2017).

Dashed lines in Figures 1B denote trends for the $27 \mathrm{EU}$ countries in our sample, while the solid line denotes the average across these countries. certainly constitutes such an event, raising the question of whether this political earthquake in North America has led to tectonic shifts in public opinion on another continent-specifically, did Trump's surprise victory affect the EU's popularity in Europe?

In search of an answer, our study takes the "shock" element described earlier literally and treats the U.S. election as a natural experiment in which the victory of Trump constitutes an external shock in the sense of experimental research. We are not the first to have this idea. Silver argued that "the May and December [2016] elections in Austria made for an interesting controlled experiment. The same two candidates were on the ballot, but in the intervening period Trump had won the American election." However, months and months in which countless potentially significant events happened over and above Trump's victory lie between these two measurement points, making Silver's claim contestable. His "setup" is not actually "controlled," and causal claims are accordingly hard to make. By contrast, we exploit the felicitous circumstance that a Eurobarometer survey was conducted during a gapless period running from precisely six days prior to six days after the U.S. election (figure 2). This exceptionally fortunate setup makes it possible to test causally whether the EU became more-or less-popular as a response to Trump's victory. To do so, our research compares the group of respondents who were surveyed prior to the election (control group) to those interviewed after Trump's victory (treatment group).

Such natural experiments are a novel methodological approach in the social sciences that has become increasingly popular in recent years. Past work has, for instance, used terrorist attacks, ${ }^{10}$ football match victories, ${ }^{11}$ celebrity suicides, ${ }^{12}$ exposure to refugee arrivals, ${ }^{13}$ selective passage of right-to-carry concealed handgun laws, ${ }^{14}$ political devolution, ${ }^{15}$ and electoral quotas ${ }^{16}$ as external shocks. By taking this innovative method to a new context, this study makes two important contributions over and above the immediate relevance of knowledge about the relation between the incumbent U.S. president and the EU. First, it adds to the fields of regional integration research and EU studies by showing how an exceptional historical event can affect public support for integration. While most past research on public support for European integration has focused on monitoring longterm trends ${ }^{17}$ and exploring the underlying social stratification, ${ }^{18}$ a growing number of studies has looked at the effect of particular events, from EU summits, ${ }^{19}$ corruption scandals, ${ }^{20}$ and the EU's receipt of the Nobel Peace Prize ${ }^{21}$ to the Euro crisis, ${ }^{22}$ the refugee crisis, ${ }^{23}$ Brexit, ${ }^{24}$ and a media boycott. ${ }^{25}$ Our study adds to this growing corpus by revealing the instant impact of a singular and particularly salient event from one day to the next on these ostensibly inert public opinion structures. Furthermore, 


\section{Figure 2 Relative frequency of observations (Eurobar- ometer 86.2)}

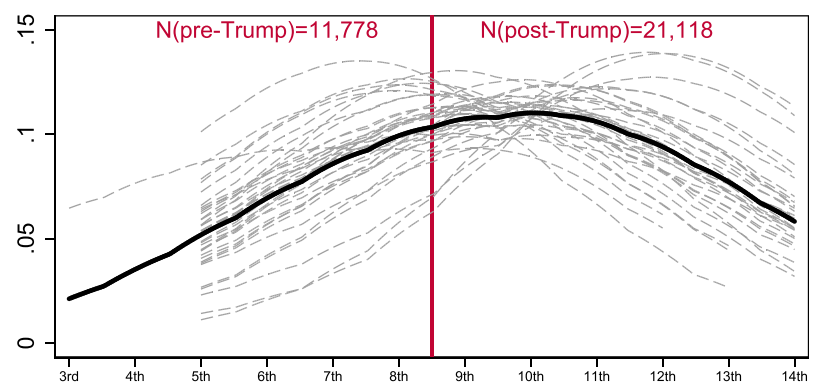

Dashed lines in Figure 2 denote all countries available in Eurobarometer 86.2, solid line denotes their average.

Deviations to the actual final sample exist (refer to the Data and Sample section).

by examining how post-election opinion dynamics varied between societal subgroups, we reveal event-driven sociopolitical shifts in the EU's base of support. Our analysis may thus also aid in understanding current changes in the position of the European right toward the EU.

Second, by combining two hitherto disconnected theories on political dynamics that predict opposing effects - the rally theory and the domino theory-and testing them on a new empirical case, this study contributes, more generally, to knowledge regarding the complex, unintended, and partially unpredictable and counterintuitive dynamics that political events in one part of the world can have in another. As we will show, a reinforced spread of nationalism to Europe (domino effect) appeared just as plausible at the outset as its opposite, a positive rally effect. Yet empirically the rally effect prevailed.

We proceed as follows: first, we lay out the competing theories of how Trump's unexpected victory could have affected the EU's popularity. Thereafter, we introduce the research design in more detail. Next, the results are presented, focusing consecutively on the overall impact Trump's election has had on the EU's popularity, a couple of subgroup analyses, and a summary of robustness checks that were run (which are available in full in the online appendix). We conclude with a summary and discussion of the findings.

\section{The Puzzle: Three Plausible, Yet Mutually Exclusive Potential Outcomes}

Three different effects of the election of Donald Trump on the EU's popularity in Europe are theoretically plausible: (a) an increase, (b) a decrease, and (c) a non-effect. In the following, arguments for and mechanisms behind each of these potential outcomes are discussed and competing hypotheses are formulated.
All of them are credible, making it difficult to formulate assumptions about the adequacy of one of them-and the falsity of the others-ex ante. Instead, we subject these competing hypotheses of rival theories to a fair test. $^{26}$

\section{Arguments for a Positive Rally Effect}

The first plausible effect of Trump's surprise victory is a higher popularity of the EU in Europe. The central mechanism behind such a positive impact could be a rally effect. The term, in its full notation- "rally-'round-theflag effect" - was originally used to describe rises in the U.S. president's popularity in the wake of international crises. ${ }^{27}$ By now, scholars have already uncoupled the "rally effect" from this initially strict focus and replaced the popularity of the U.S. president with trust in government, the ruling party, other leaders, or general public opinion in the United States and other countries as the dependent variable. ${ }^{28}$ It is possible to dissociate this idea further from its narrow original context to make the general argument that a perceived external threat can bring members of a social entity to unite. A similar proposition can be found in Karl Deutsch's transactionalist theory of integration. ${ }^{29}$ Admittedly, Deutsch and colleagues speak of unifying effects of an external military threat, and in present days Europeans certainly do not fear a direct attack by the United States against Europe. However, many Europeans are indeed worried about the unpredictability of Donald Trump as the commander-in-chief of the world's largest military force. ${ }^{30}$ Yet more importantly, no reason is immediately apparent why this mechanism should not work similarly for sociopolitical threats more generally. In the present case, the sudden election of Trump as an American nationalist could be subjectively experienced to pose an external threat to the stability and prosperity of Europe. As mentioned earlier, observers suspected that his election would affect transatlantic relations and prospects of European integration. Such concerns were fueled prior to the election by Trump's nationalist credo "America first," condemnatory statements about NATO and TTIP, and consentient comments regarding the looming partial breakup of the EU in the wake of Brexit. ${ }^{31}$ One fear was thus the need to reinvent Europe's role in the world upon realizing that the United States is no longer a reliable partner. As stated by Angela Merkel in May 2017 after meeting with Trump, Europe "really must take our fate into our own hands." 32 Thus, it is possible that already in immediate response to Trump's unexpected victory, Europeans rallied around the European "flag" — creating a feeling of unity that could be measurable through an increased popularity of the EU.

Notably, Hannah Arendt made a similar argument in the first half of the twentieth century, stating, "If it is true that each nationalism . . . begins with a real or fabricated common enemy, then the current image of America in 
Europe may well become the beginning of a new pan-European nationalism." 33 She evaluated this "antiAmerican Europeanism" "34 negatively, as nationalistic with ties to fascism and in opposition to a liberal federalism. Hence, a unifying effect through an external threat may work for liberal cosmopolitans just as for conservative nationalists. The former may move toward increased EU support, seeing it as a stronghold of an open, postnationalist world, while the latter may embrace Europe as a bastion in a world of strong and nationalistic regional powers, such as the United States, China, and Russia.

More recent research has also looked deeper into the question of who is most susceptible to rally effects. Baum argues that while different social groups may have varying propensities to engage in rallying, individuals who are closest to the point of ambivalence between approval and disapproval on the issue in question are most likely to change their opinion. ${ }^{35}$ Colaresi suggests that rally effects do not require an emotional or irrational public but can be modeled as a rational response to international crises. ${ }^{36}$ Baker and Oneal additionally find that the size of a rally effect is influenced by how the media covers the event in question, potentially making differences in media consumption a significant factor. ${ }^{37}$

Recently, it has been argued that Brexit-a victory for right-wing populism in many ways comparable to Trump's election - may be responsible for a rise in Eurobarometer respondents who say they "feel like citizens of the EU." 38 The adequacy of this claim has not yet been corroborated through a rigorous causal analysis. But if the assessment is correct, it could suggest that a similar positive effect, in which Europeans rally around "their flag" in defiance of nationalist sentiment, may be at work in the case of Trump. We can thus formulate as a first hypothesis that

$\mathrm{H}_{1}$ : Trump's election increased the EU's popularity in Europe (rally effect).

At the same time, however, arguments for the opposite case, a negative domino effect, have been made.

\section{Arguments for a Negative Domino Effect}

Another plausible outcome is a decrease in the EU's popularity in the wake of Trump's surprise victory. The underlying mechanism could be a domino effect in which the United States' "fall" for right-wing populism constitutes the start of a chain reaction in which other countries-e.g., in Europe-successively "tilt over," resulting in rising levels of nationalism and antisupranationalism. Although domino theory originated in the cold war context of countries supposedly acceding consecutively to communism, it has been applied to other contexts, such as democratization, ${ }^{39}$ regionalism, ${ }^{40}$ and, most recently, populism after Brexit. ${ }^{41}$ Thus, it does not appear far-fetched to apply domino theory to the spread of right-wing populism (and an according decline of supranationalism) after Trump's success. In the present case, the domino effect could mean lower popularity levels for the EU due to a combination of resignation among cosmopolitans and reinforcement of nationalists in their beliefs.

In Europe, fears of such a domino effect were visible in public discourses prior to the national elections in Austria (December 2016), the Netherlands (March 2017), France (April-May 2017), and Germany (September 2017). Many observers anticipated significant political shifts to the right, often naming Trump's victory as one ground for their expectance. Mudde, for instance, argued, writing immediately after the U.S. election, that "the surprise win of Donald Trump is a gift from heaven for the far right around the globe." Their victory in the United States, he suspected, "gives them a narrative of hope and success." 42 New impetus to right-wing populism should go hand in hand with increased Euroscepticism ${ }^{43}$ and thus a less popular EU. Research shows that this link has become even stronger during recent years. ${ }^{44}$ Thus, a competing hypothesis to $\mathrm{H}_{1}$ would be that

$\mathrm{H}_{2}$ : Trump's election decreased the EU's popularity in Europe (domino effect).

To some extent, however, converse trends became observable in the months after the U.S. presidential election, making concerns over a domino effect appear somewhat exaggerated in hindsight. ${ }^{45}$ Yet it is still unclear which form the Trump effect on the EU's popularity took immediately after the election. Was it a positive rally effect, a negative domino effect—or rather no effect at all?

\section{Arguments for a Non-Effect}

A non-effect could simply be the outcome of no effect, if

$\mathrm{H}_{0}$ : Trump's election did not affect the EU's popularity in Europe.

A more complex "non-effect" could result from positive effects and negative effects (partially) offsetting each other. To arrive at an understanding of how such a canceling out could come about, it is necessary to compare different social subgroups. We look at two ${ }^{46}$ specific potentially relevant societal divides: first, subgroups defined by the (perceived) economic situation of the respondents' country. Here, the way Europeans rate the economic situation of their country serves as a proxy for the degree to which they feel their country has been affected by the economic crises in the EU. The underlying idea is that in economically struggling countries, the EU will likely have low initial popularity levels but potentially high upward momentum, whereas in economically thriving countries that are hardly affected by the crises, the EU likely has comparatively high initial popularity but low potential for upward momentum (ceiling effect). We thus expect that

$\mathrm{H}_{3 \mathrm{~A}}$ : Trump's election has had different effects on the EU's popularity among respondents who perceive their country as 
economically struggling as opposed to those who perceive it as economically well off.

Second, we look at Europeans' political orientation. As discussed in the preceding sections, people with different political orientations could react differently to Trump's surprise victory. It is plausible that the EU has high initial popularity levels among the political center and lower ones among the left and the right. ${ }^{47}$ This could again be connected to little upward momentum among the center (which likely tends to be very much in favor of the EU already prior to the election) whereas the right and the left may be more susceptible to changing their views on the $\mathrm{EU}$ in response to the unexpected coming to power of a right-wing nationalist in the United States (cf. the argument by Baum presented earlier). Dissecting the Trump effect on the EU's popularity by political orientation will shed light on these potentially diverging effects and to test whether they (partially) cancel each other out. We thus assume that

$\mathrm{H}_{3 \mathrm{~B}}$ : Trump's election has had different effects in the political subgroups of the European population.

\section{Research Design}

Our research design exploits the fact that the 2016 U.S. presidential election took place amid the fieldwork of a Eurobarometer survey. An explanation follows of how this fortunate coincidence makes it possible to solve the fundamental problem of causal inference and thus to estimate causally the effect of Trump's victory on the EU's popularity in Europe.

\section{Solving the Fundamental Problem of Causal Inference}

In order to estimate the causal effect of a treatment $T$, a study setup is required that allows the same (or very similar) observations to be exposed to treatment and control simultaneously. ${ }^{48}$ However, observing treatment and control outcomes for the same observation at the same time, that is, the counterfactuals of each state, is impossible. To be able to distinguish correlation from causation despite this "fundamental problem of causal inference," ${ }^{49}$ a few conditions must be fulfilled. First, the assumption of independence must be satisfied, ensuring that differences in outcome between treatment and control group are only due to the treatment. One possibility to meet this assumption is randomization. If the treatment is assigned randomly to participants, no observable or unobservable factors can bias potential outcomes. While randomization is easily achieved in laboratory experiments given that assignment to treatment can be manipulated by the researcher, studies based on observational data rarely meet this strict assumption. Sometimes, however, randomization-like conditions occur naturally, allowing researchers to draw causal inferences based on observational data. In such natural experiments, the treatment is randomized not through manipulation by the researcher, but by an event that is exogenous to the outcome in question. Thus, in natural experiments, individuals are exposed to the treatment as-if random. ${ }^{50}$

Our research design meets the as-if random criterion of a natural experiment and thus satisfies the independence assumption: The U.S. presidential election took place between the sixth and the seventh day of the Eurobarometer's 12-day fieldwork (see figure 2). Being assigned to an interview date before or after the presidential election was random, since it did not depend on the respondents' political preferences, socio-economic characteristics, or other observable or unobservable confounders. Thereby, the outcome (change in the popularity of the EU among respondents) should be related to nothing but the assignment to treatment, namely, being interviewed before or after the election.

Table 1 shows that this as-if random criterion actually holds empirically. It provides a summary of descriptive statistics on a range of widely used socio-economic and demographic variables in our sample, including age, gender, education in years (top-coded at 26), occupation, and a dichotomous variable indicating whether the individual lives in the countryside or in a town. As can be seen from the $\Delta$ means column, the sample is mostly well balanced, with no significant differences in education, gender, or place of living between the treatment and the control group. For age and some occupational classes, minor differences can be found. For instance, the mean age in the treatment group is 49.2 years, compared to 50.8 in the control group. To correct for these small divergences, one of our models controls for the variables depicted in table 1 (see equation 2). Furthermore, robustness checks were run in which older respondents were excluded (leading to an entirely balanced sample), and in which the potential influence of betweencountry differences in the distribution of fieldwork across time (see figure 2) were tested. All robustness checks confirm the validity of our conclusions. ${ }^{51}$

Additionally, it is necessary to have plausible evidence that people "complied" with the treatment, that is, that they were aware that Donald Trump was elected president. The Google Trends data depicted in figure 1B reveal that in each and every European country contained in the Eurobarometer, the relative amount of online searches targeting "Donald Trump" spiked to its maximum on the day following the election (dashed lines). The universality and extreme nature of this pattern strongly suggest that most people became aware of Trump's election as president very quickly. While, of course, not everybody uses the Internet, there are good reasons to assume that the general public soon took notice of the surprise victory of the Republican candidate, making it a legitimate treatment in a natural experiment.

Furthermore, the exclusion restriction needs to be fulfilled. ${ }^{52}$ That is, it is necessary to be certain that no 
Table 1 Descriptive statistics

\begin{tabular}{|c|c|c|c|c|c|c|c|c|c|}
\hline & \multicolumn{4}{|c|}{ Control group $(\mathrm{N}=6,395)$} & \multicolumn{4}{|c|}{ Treatment group $(\mathrm{N}=9,890)$} & \multirow[b]{2}{*}{$\Delta$ means } \\
\hline & Mean & SD & Min & Max & Mean & SD & Min & $\operatorname{Max}$ & \\
\hline EU popularity index & -0.074 & 1.06 & -3.02 & 2.62 & 0.045 & 1.05 & -3.02 & 2.62 & $-0.120^{\star \star *}$ \\
\hline Education (in years) & 17.869 & 6.18 & 0 & 26 & 17.841 & 6.10 & 0 & 26 & 0.028 \\
\hline Female & 0.506 & 0.50 & 0 & 1 & 0.515 & 0.50 & 0 & 1 & -0.008 \\
\hline \multicolumn{10}{|l|}{ Occupation } \\
\hline Self-employed & 0.071 & 0.26 & 0 & 1 & 0.080 & 0.27 & 0 & 1 & $-0.009^{\star}$ \\
\hline White collar & 0.243 & 0.43 & 0 & 1 & 0.259 & 0.44 & 0 & 1 & $-0.016^{\star}$ \\
\hline Manual worker & 0.186 & 0.39 & 0 & 1 & 0.203 & 0.40 & 0 & 1 & $-0.175^{\star \star}$ \\
\hline Homemaker & 0.044 & 0.20 & 0 & 1 & 0.044 & 0.21 & 0 & 1 & -0.000 \\
\hline Unemployed & 0.066 & 0.25 & 0 & 1 & 0.067 & 0.25 & 0 & 1 & -0.001 \\
\hline Retired & 0.323 & 0.47 & 0 & 1 & 0.280 & 0.45 & 0 & 1 & $0.043^{\star \star \star}$ \\
\hline Student & 0.066 & 0.25 & 0 & 1 & 0.066 & 0.25 & 0 & 1 & -0.000 \\
\hline Age & 50.838 & 18.0 & 15 & 96 & 49.246 & 17.5 & 15 & 98 & $1.591^{\star \star \star}$ \\
\hline Urban $(=1,0=$ rural $)$ & 0.689 & 0.46 & 0 & 1 & 0.696 & 0.46 & 0 & 1 & -0.007 \\
\hline
\end{tabular}

Note: Based on Eurobarometer 86.2, own calculations, not weighted;

$\mathrm{SD}=$ Standard deviation, education was top-coded at 26 years to reduce the influence of outliers

${ }^{\star} \mathrm{p}<0.05,{ }^{\star \star} \mathrm{p}<0.01,{ }^{\star \star *} \mathrm{p}<0.001$

other events over and above the election influenced the outcome. For this, Google Trends data can again help. Exploring trending topics on Google during the examined time frame reveals that "election" (relative rank in Google searches: 4), "Trump" (6), "election results" (16), "Donald Trump" (17), "election 2016" (18), "Clinton" (23), and "polls" (24) were the dominating date-specific keywords. All other high-ranking keywords relate to unspecific everyday interests, including "Facebook" (1), "YouTube" (2), "Google" (3), "you" (5), "news" (7), "Gmail” (8), "fb" (9), and "Hotmail" (10). This suggests that during the time-span under study, there were no other relevant events that could distort the results. While not salient in the Google Trends data, it should be noted that several European countries commemorate the end of World War I, the Holocaust, and the end of communism in Eastern Europe during the time frame under study. To exclude the possibility that these holidays are responsible for a potential change in the EU's popularity (due to the EU becoming salient as a peace project in people's minds during these days), we ran a robustness check in which we excluded countries that have such public commemorations from the analysis. Results reconfirm the main findings. Furthermore, we replicated the analysis with an earlier Eurobarometer from 2013 and did not find a similar effect, confirming that the observed effect is due to the singular event of Trump's election. ${ }^{53}$

Finally, it is necessary to show that the premise of considering the presidential election as an exogenous event is actually valid. The election would not have been exogenous if Europeans could have anticipated Trump's victory and started adapting attitudes on the EU already before the election took place. However, figure 1A illustrates that basically no one-not even political insiders-expected Trump to win, and polls remained in Clinton's favor until the election night. European media outlets also speak of "one of the most improbable political victories in modern U.S. history" ${ }^{154}$ and argue that no one saw the victory of Donald Trump coming. ${ }^{55}$ Thus, it is very unlikely that ordinary citizens had adapted their attitudes before the election took place. ${ }^{56}$ Another argument in favor of exogeneity is that Europeans were, of course, not the ones who went to the ballot boxes in the U.S. election. Thus, arguing that they could anticipate Trump's win because they were planning on voting Trump into office is implausible. In the wake of the U.S. election, Europeans merely knew that Trump's becoming the next president was-according to polls and media reports-highly unlikely. All this provides a high degree of certainty that Trump's election took Europeans by surprise and thus acted as an exogenous shock.

\section{Data and Sample}

The Eurobarometer is a large-scale cross-sectional public opinion survey, conducted on behalf of the European Commission. The survey program started in 1974 and is released biannually. Here, we draw on the Eurobarometer 86.2, which contains data from 35 European countries, collected between November 3 and 14, 2016. In the sample for this study, all non-EU member states were excluded, since several central items were not included in these countries' questionnaires. To increase consistency, Bulgaria was also excluded, because the data collection started and ended two days earlier there than everywhere 
else (cf. figure 2). All other $27 \mathrm{EU}$ member states are contained in the analysis. Following best practice from a range of previous research, ${ }^{57}$ respondents who were interviewed immediately after the external shock (on November 9) were excluded to ensure that respondents in the treatment group actually had time to become aware of the fact that Donald Trump was elected president. The number of observations in the sample was additionally reduced by listwise deletion of missing cases in creating the dependent variable (refer to the next section). The final sample contains 16,285 observations.

\section{Dependent Variable (DV)}

The study used 12 items from the Eurobarometer to construct an aggregate measure of EU popularity (see table 2). ${ }^{58}$ All 12 items are based on a 4-option Likert scale and measure certain positive attitudes toward the EU (e.g., agreement with statements such as "the EU is modern," "the EU is efficient," or "the EU creates jobs"). Employing exploratory factor analysis, only one factor with an Eigenvalue $>1$ (5.17) emerges, on which all items load with at least .55. Thus, following commonly accepted standards, ${ }^{59}$ all 12 items have good to excellent factor loadings. The onefactor solution was confirmed by various adjustments and robustness measures based on different sets of variables, as well as various rotation techniques. Furthermore, given that the variables in question were not discrete but categorical, the results were reconfirmed by using polychoric factor analysis, a procedure that makes it possible to perform factor analysis with categorical variables. Since the results resembled those from the conventional factor analysis, it was decided to adhere to the standard procedure. Employing the respective factor, the DV was extracted by using the Bartlett method.

\section{Treatment Variable and Subgroup Splitting}

To measure the Trump effect, a treatment variable was created that captures whether the respondent was interviewed prior $(T=0$, control group, November $5-8, \mathrm{~N}=$ $6,395)$ or after $(T=1$, treatment group, November 10 $14, \mathrm{~N}=9,890)$ the U.S. presidential election. For the subgroup analyses, the sample was first divided into four subgroups based on how respondents perceived the economic situation of their country ("very good," "rather good," "rather bad," or "very bad"). Individual-level political orientation, the second variable used to split the sample into subgroups, was inquired in Eurobarometer 86.2 through the question "In political matters people talk of 'the left' and 'the right.' How would you place your views on this scale?" The scale, which was shown to respondents, had ten categories ranging from 1 ("left") to 10 ("right"), with the middle categories remaining unspecified. In line with common practice, ${ }^{60}$ respondents were grouped into the three meta-categories "left" (1-4), "center" (5-6), and "right" (7-10) for the subgroup analyses. For several additional subgroup analyses and corresponding variable descriptions, see the online appendix, items 5,7 , and 8 .

\section{Control Variables}

Operating within the framework of a natural experiment, it is not necessary to adjust for covariates, as the treatment is randomly assigned and individual socio-economic and unobserved characteristics should thus not vary before and after the treatment. However, covariates can be included to estimate the treatment effect more precisely and to control for smaller imbalances between treatment and control group. ${ }^{61}$ Those variables, however, should be strictly exogenous. As discussed earlier, the sample is

\section{Table 2}

Elements of the EU popularity index

\begin{tabular}{lcc}
\hline Variable & Factor loadings & Uniqueness \\
\hline 1. EU is modern & 0.6575 & 0.5677 \\
2. EU is democratic & 0.7171 & 0.4858 \\
3. EU is protective & 0.7019 & 0.5074 \\
4. EU is efficient & 0.6914 & 0.5220 \\
5. EU is forward looking & 0.7304 & 0.4665 \\
6. Optimistic for the EU's future & 0.6807 & 0.5366 \\
7. EU creates jobs & 0.6415 & 0.5885 \\
8. EU makes business easier & 0.5514 & 0.6960 \\
9. Satisfaction with democracy in EU & 0.6918 & 0.5214 \\
10. Feeling attached to the EU & 0.5902 & 0.6516 \\
11. Feel like being a EU citizen & 0.5835 & 0.6595 \\
12. EU respects own country's interests & 0.6125 & 0.6248 \\
Eigenvalue & 5.1721 & \\
\% Variance & 0.9676 & 0.8929 \\
Cronbach's alpha & &
\end{tabular}

Note: Based on Eurobarometer 86.2 
mostly well balanced, but some minor differences between treatment and control group do exist (cf. table 1). To correct for these small imbalances and to increase precision, the variables listed in Table 1 were included as controls in one of the models (see equation 2).

\section{Method}

We use a regression discontinuity $(\mathrm{RD})$ design. We start with a parsimonious model that employs OLS regression with the EU popularity index as DV and the treatment dummy (= Trump effect) as independent variable. Robust standard errors were estimated as recommended in the literature. ${ }^{62}$ In formal terms, the base model can thus be described as:

$$
y=\alpha+\delta T+\varepsilon,
$$

where $\delta$ stands for the effect of the treatment $T$, namely, being interviewed on the EU's popularity after Trump's election; $\alpha$ represents the intercept; and $\varepsilon$ is an error term. Next, the earlier-mentioned control variables $X$ were included to estimate the treatment effect $\delta$ more precisely:

$$
y=\alpha+\delta T+\beta X+\varepsilon
$$

In a last step, a more conventional form of the $\mathrm{RD}$ design was implemented by testing for varying slopes in the EU's popularity before and after the U.S. presidential election. This was accomplished by including the interaction between time to election and the treatment variable:

$$
y=\alpha+\delta T+\beta(Z-c)+\gamma T(Z-c)+\beta X+\varepsilon
$$

where $Z$ stands for the day of the interview and $\mathrm{c}$ represents the critical point at which the treatment status changes, in this case, the election night. It follows that $\beta(Z$ $-c$ ) represents the effect of a mean-centered time variable based on the interview date, which is set to zero at November 10. The term $\gamma T(Z-c)$ stands for the interaction effect between the treatment variable and the mean-centered interview date variable. Using this interaction effect, the slope of the centered interview variable was allowed to vary before and after the treatment. Additionally, in equation $3, \delta T$ no longer depicts the treatment effect for the period spanning November $10-14$ as in equations 1 and 2. Rather, $\delta T$ now represents the immediate causal effect of Trump's election on the EU's popularity on November 10, that is, the day that now is specified to be the first day after the election $(Z=c$ for $\delta T$ in equation 3). Thus, it is now possible to test for an instant, "overnight" Trump effect.

It might be argued that, in contrast to equation 3, equations 1 and 2 are not conventional implementations of the $\mathrm{RD}$ technique, as they solely employ a dummy and no additional linear treatment estimator or its corresponding polynomials. ${ }^{63}$ However, given the Eurobarometer's short time frame-which may make pinpointing the discontinuity to exactly November 10 unnecessary - and a general interest in parsimonious models, we would still like to test the first two specifications. Following the stepwise procedure of looking at equations 1 to 3 consecutively is therefore considered the most sensible approach. A range of previous research has used similar strategies in estimating $\mathrm{RD}$ regressions. ${ }^{64}$

In the graphical representations of the findings (figures 3-5), all independent variables except the treatment effect are mean-centered. This mean-centering facilitates interpretation since the intercept $\alpha$ now represents a meaningful estimate, that is, the EU's popularity for the average European citizen prior to Trump's win, while $\alpha+\delta T$ illustrates the average popularity after the election.

\section{Results}

\section{Overall Effect}

Table 3 shows three models that predict the overall Trump effect on the EU's popularity across all $27 \mathrm{EU}$ member states under study. In line with equation 1 , model 1 contains only the treatment effect, which is positive and highly significant $\left(\delta^{\mathrm{RD}}=.120, \mathrm{p}<.001\right)$. Thus, Trump's victory appears to have increased rather than decreased the EU's popularity, lending support to the rally- $\left(\mathrm{H}_{1}\right)$ rather than the domino- $\left(\mathrm{H}_{2}\right)$ or the no-effect hypothesis $\left(\mathrm{H}_{0}\right)$.

Model 2 adds country dummies and a range of control variables as described in equation 2 to account for the fact that not all covariates are perfectly balanced between the treatment and the control group. The effects of the control

\section{Figure 3 \\ The overall "Trump effect" on the EU's popu- larity}

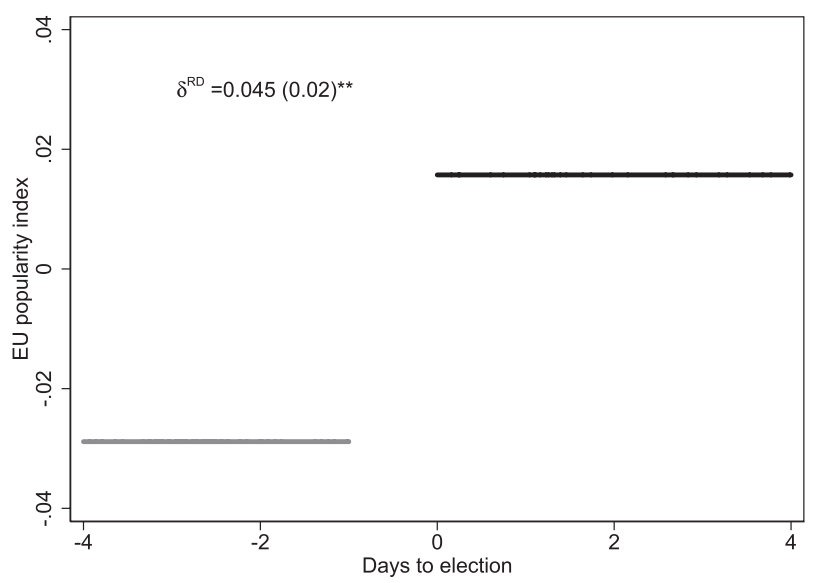

Note: Based on the regression presented in Table 3, Model 2. Control variables, including the country dummies, are set to their mean value. ${ }^{*} p<0.05,{ }^{\star *} p<0.01$, ${ }^{\star \star \star} p<0.001$. 


\section{Figure 4 \\ Treatment effect of the U.S. presidential election; subgroup analysis by perceived economic situation of the country}
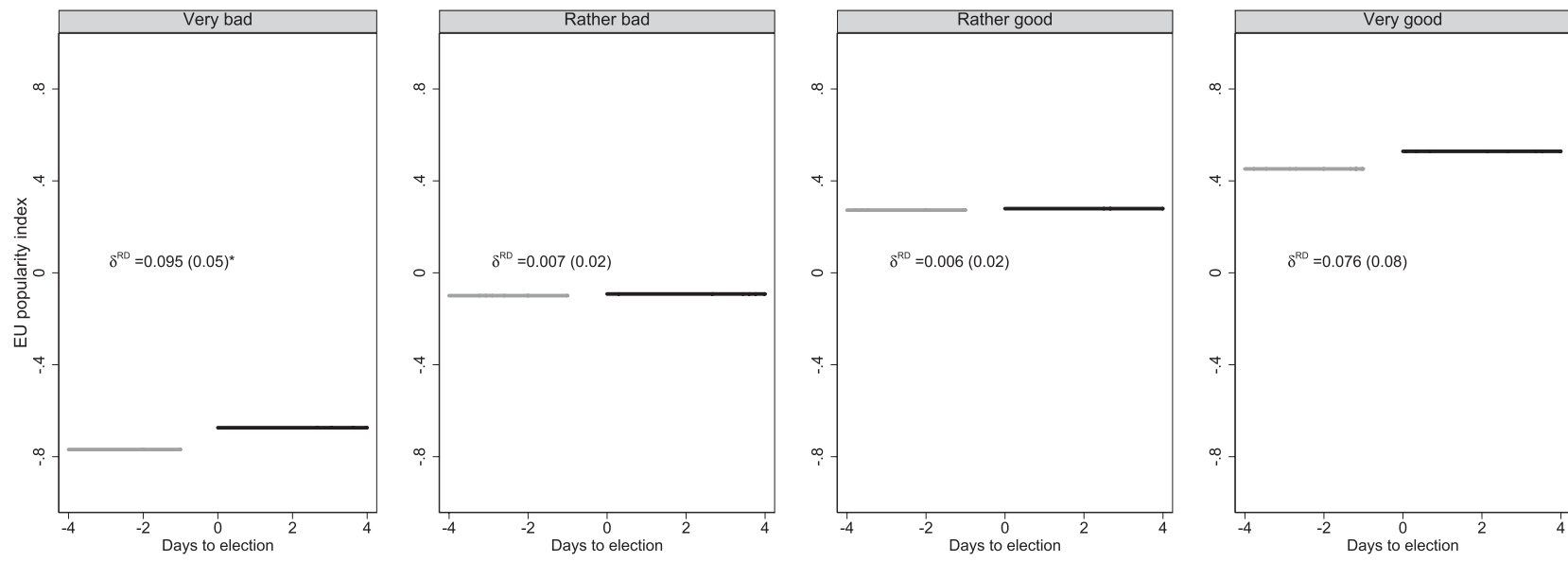

Note: Based on the regressions presented in table A1.

Control variables, including the country dummies, are set at their mean value.

${ }^{*} p<0.05,{ }^{* *} p<0.01,{ }^{* \star *} p<0.001$.

variables all go in expectable directions, in line with the existing literature on EU support: ${ }^{65}$ the EU is more popular among the urban population, the better educated, the younger, and those in better-paying (white-collar) positions. The Trump effect becomes somewhat smaller in size but remains significant $\left(\delta^{\mathrm{RD}}=.045, \mathrm{p}<.01\right)$. Despite this decrease, it is still considerable: the effect of being interviewed after Trump's victory is roughly equivalent to the effect that three additional years of education have on a person's opinion of the $\mathrm{EU}\left(3 \times \beta^{\text {edu }}=\right.$ $\left.3 \times .014=.042<\delta^{R D}=.045\right)$. Since education has repeatedly been shown to be one of the key predictors of pro-EU attitudes, ${ }^{66}$ the Trump effect seems anything but negligible. To draw one more comparison, the Trump effect is also about two-thirds the size of the rural-urban divide, another major cleavage in contemporary societies. All this suggests that Trump's election has had a substantial effect on the EU's popularity in Europe. The explained variance increases from .3 to 13.6 percent from model 1 to model 2 .

Model 3 includes an additional check on whether allowing for slope variance (i.e., up- or downwardpointing trends during the days prior and after the election) leads to a more accurate description than the previous model. As discussed earlier, $\delta^{\mathrm{RD}}$ now represents the immediate, overnight Trump effect (cf. equation 3). Model 3 illustrates that there was a significant and prompt European reaction to Trump's win, namely, an increase of the EU's popularity by $\delta^{\mathrm{RD}}=.077$. The non-significant effects of days $\left(\beta^{\text {days }}=-.013, \mathrm{p}>.05\right)$ and the interaction between treatment and days $\left(\delta^{\mathrm{RD}} \times \beta^{\text {days }}=.013\right.$, $p>.05)$ show that the Trump effect was an overnight effect and that no further meaningful change occurred in the following days. In line with this, the non-increase in explained variance (still $\mathrm{R}^{2}=.136$ ) suggests that allowing for slope variance does not improve the quality of the model. Accordingly, we proceed with the specifications of the more parsimonious and equally powerful model 2 in our further analysis.

Figure 3 shows graphically the overall effect as specified in model 2. It illustrates that the EU's popularity in Europe increased significantly $\left(\delta^{\mathrm{RD}}=.045, \mathrm{p}<.01\right)$ after the election of Donald Trump. Specifically, average popularity rates rose from a negative popularity rate of $-.029(\alpha)$ prior to Trump's success to a positive one of .016 $(\alpha+\delta T)$ in the election's aftermath (results from mean-centered model, not shown). We can thus conclude that a positive rally effect rather than a negative domino effect or no effect occurred immediately after Trump's surprise victory. The following section looks at whether this positive effect occurred in all specified subgroups, or whether social divides can be observed in line with $\mathrm{H}_{3 a}$ and $\mathrm{H}_{3 \mathrm{~b}}$.

\section{Subgroup Analyses}

Dividing the sample by the respondents' perception of their country's economy reveals a first meaningful fault line. While the EU became significantly more popular among respondents who perceived their countries' economy as "very bad" after the election, respondents who thought of it as "rather bad," "rather good," or "very good" did not significantly change their attitudes toward the EU (figure 4, cf. table A1 for the full model statistics). Thus, it appears that it was specifically respondents who perceived their countries as ridden by economic turmoil 
Figure 5

Treatment effect of the U.S. presidential election; subgroup analysis by partisanship
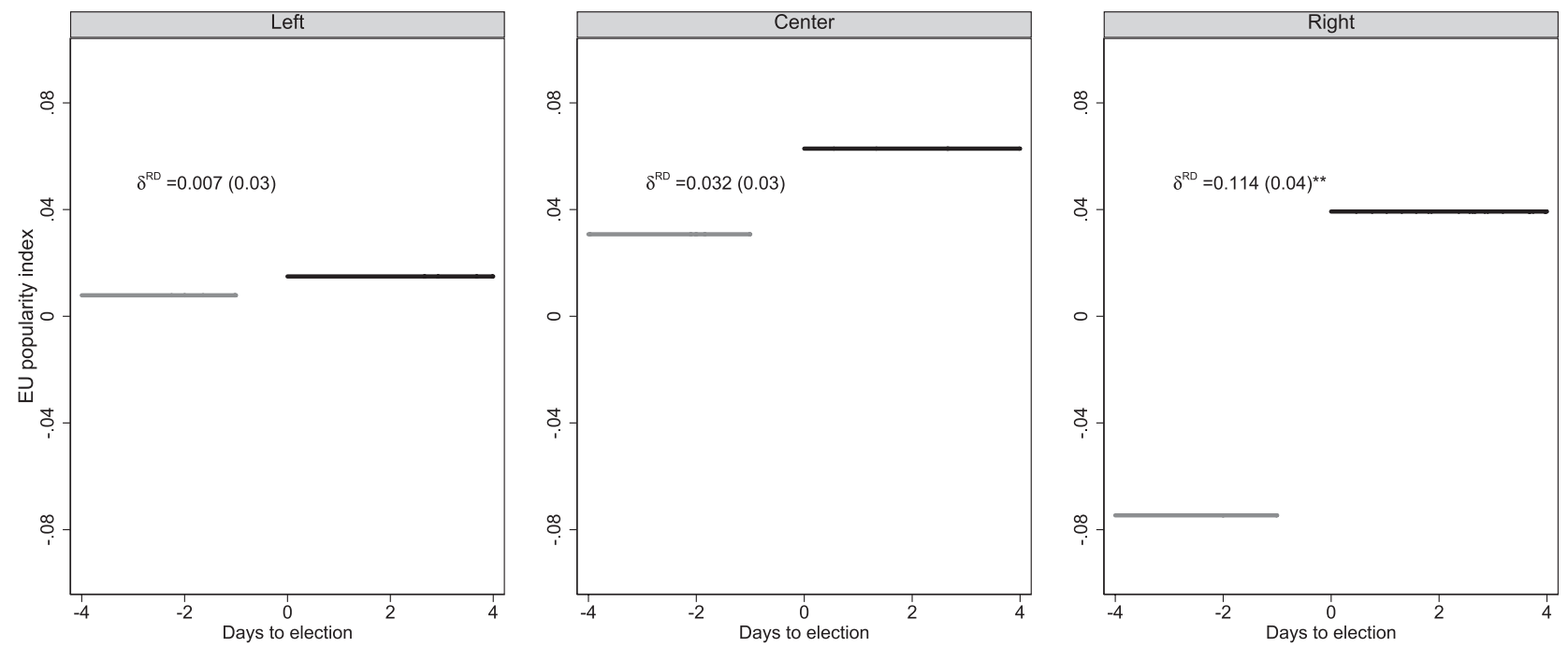

Note: Based on the regressions presented in table A2.

Control variables, including the country dummies, are set at their mean value.

${ }^{*} p<0.05,{ }^{* *} p<0.01,{ }^{* *} p<0.001$.

that rallied 'round the EU's flag in response to the Trump shock. Additional analyses based on a subgroup division by national unemployment rate and change in unemployment rate reconfirm this picture. ${ }^{67}$
Subgroup analyses by political orientation disclose a second meaningful divergence (figure 5, table A2). In line with existing research, the EU was initially most popular among the political center (EU popularity index

\section{Table 3}

\section{OLS regression; DV: EU popularity index}

\begin{tabular}{|c|c|c|c|c|c|c|}
\hline \multirow[b]{2}{*}{ Treatment group (1=yes) } & \multicolumn{2}{|c|}{ (1) } & \multicolumn{2}{|c|}{ (2) } & \multicolumn{2}{|c|}{ (3) } \\
\hline & $0.120^{* * *}$ & $(0.02)$ & $0.045^{\star \star}$ & $(0.02)$ & $0.077^{\star}$ & $(0.03)$ \\
\hline Treatment*Days & & & & & 0.013 & $(0.01)$ \\
\hline Days (mean-centered) & & & & & -0.013 & $(0.01)$ \\
\hline Female $(1=$ yes $)$ & & & 0.029 & $(0.02)$ & 0.029 & $(0.02)$ \\
\hline Age & & & $-0.004^{\star \star *}$ & $(0.00)$ & $-0.004^{\star \star \star}$ & $(0.00)$ \\
\hline \multicolumn{7}{|l|}{ Occupation } \\
\hline White collar & & & (ref) & & (ref) & \\
\hline Self-employed & & & -0.055 & $(0.03)$ & -0.054 & $(0.03)$ \\
\hline Manual & & & $-0.114^{\star \star \star}$ & $(0.02)$ & $-0.114^{\star \star \star}$ & $(0.02)$ \\
\hline Homemaker & & & $-0.116^{\star \star}$ & $(0.04)$ & $-0.115^{\star \star}$ & $(0.04)$ \\
\hline Unemployed & & & $-0.357^{\star \star \star}$ & $(0.04)$ & $-0.356^{\star \star \star}$ & $(0.04)$ \\
\hline Retired & & & -0.053 & $(0.03)$ & -0.052 & $(0.03)$ \\
\hline Student & & & $0.442^{\star \star \star}$ & $(0.06)$ & $0.441^{\star \star \star}$ & $(0.06)$ \\
\hline Urban $(=1,0=$ rural $)$ & & & $0.073^{\star \star \star}$ & $(0.02)$ & $0.074^{\star \star \star}$ & $(0.02)$ \\
\hline Education (in years) & & & $0.014^{\star \star \star}$ & $(0.00)$ & $0.014^{\star \star \star}$ & $(0.00)$ \\
\hline Country dummies & & & $\checkmark$ & & $\checkmark$ & \\
\hline Constant & $-0.074^{\star * *}$ & $(0.01)$ & $0.155^{\star}$ & $(0.07)$ & 0.125 & $(0.08)$ \\
\hline Observations & 16,285 & & 16,285 & & 16,285 & \\
\hline$R^{2}$ & 0.003 & & 0.136 & & 0.136 & \\
\hline
\end{tabular}

Note: Treatment group: Interviewed after November 9.

Robust standard errors in parentheses.

Own calculations based on Eurobarometer 86.2, not weighted.

${ }^{\star} \mathrm{p}<0.05,{ }^{* \star} \mathrm{p}<0.01,{ }^{\star \star *} \mathrm{p}<0.001$ 
score: .031), followed by the left (.008), and least popular among the right (-.075). While it appears that the EU became slightly more popular among the political left $\left(\delta^{\mathrm{RD}}=.007\right)$ and the center $\left(\delta^{\mathrm{RD}}=.032\right)$ in the wake of the U.S. presidential election, these increases are not significant $(\mathrm{p}>.05)$. Among the right, however, a significant upward jump occurred after Trump's victory $\left(\delta^{\mathrm{RD}}=\right.$ $.114, \mathrm{p}<.01)$. The right overtook the left and remains only slightly below the center, indicating a remarkable shift in the political landscape of EU support. ${ }^{68}$ This picture can also be reconfirmed with two alternative indicators. ${ }^{69}$

\section{Robustness Checks}

To ensure that these results are not spurious, we ran a comprehensive set of thirteen robustness checks, including, inter alia, a placebo analysis, propensity score and nearest neighbor matching, as well as a correction for the minor sample imbalances observed in table 1 . Due to spatial constraints, these robustness checkswhich all support the findings presented above-are included in the online appendix. Here, just some key findings are highlighted. First, the main result of a positive and significant Trump effect on the EU's popularity could be replicated with another data set, namely round 8 of the European Social Survey. Strikingly, even the relative size of the Trump effect is similar, being again roughly equivalent to the effect of three additional years of education. We further reran the analysis using a 2012 Eurobarometer (78.1) that coincided with Barack Obama's second election as U.S. president to test whether the "Trump effect" is not actually a general "U.S. presidential election effect." No effect was found in 2012, suggesting that the significant effect observed in 2016 was uniquely connected to the personality of Donald Trump. Finally, we replicated the analysis using a 2013 Eurobarometer (80.1) that was carried out during the same time of the year to check whether the observed effect is not actually a seasonal one, possibly due to the commemoration days mentioned earlier. Again, no significant treatment effect was found, allowing us to rule out the possibility that memorial days (or any other intervening seasonal events) are the actual reason for the observed change in the EU's popularity. Thus, there is conclusive evidence that the significant increase in the EU's popularity observed in November 2016 actually occurred and that it was indeed caused by the surprise election of Donald Trump as U.S. president.

\section{Summary and Discussion}

This study treated the surprise victory of Donald Trump in the 2016 U.S. presidential election as an external shock and examined whether it led to a change in the popularity of the EU in Europe. Three main findings shall be highlighted:
1. The EU's popularity did in fact increase immediately after the election, suggesting that Trump's surprise victory caused a rally effect in Europe (in line with $\mathrm{H}_{1}$, and disproving $\mathrm{H}_{2}$ and $\mathrm{H}_{0}$ ).

2. Gains in the EU's popularity after Trump's victory were particularly high among respondents who perceived their country as economically struggling (in line with $\mathrm{H}_{3 \mathrm{~A}}$ ), revealing an economic fault line.

3. There is also a political fault line in that gains in the EU's popularity after Trump's surprise win were particularly high among the political right (in line with $\mathrm{H}_{3 \mathrm{~B}}$ ), suggesting a shift in the EU's base of support.

This study has implications regarding both the specific case it addresses and the broader dynamic that underlies it. Relating to the specific case, the findings show that the election of Trump as a right-wing nationalist with a declared aversion to supranational institutions-including the EU-did not trigger a domino effect in the same direction in Europe. To the contrary, a rally effect occurred, in which Europe moved closer together, rallying around the EU's "flag." This indicates that an event that may at first sight appear to be a global victory for nationalism can immediately trigger measurable sentiments of resistance in another part of the world, actually leading to new impetus for supranationalism.

The large gains in the EU's popularity among the political right, however, are an important qualifier. They suggest that this increased popularity of the EU is likely not primarily cosmopolitan or liberal in nature. Instead, the Trump effect appears to have given rise to a right-wing variant of pro-EU stances, akin to Hannah Arendt's idea of a non-progressive "anti-American Europeanism." This impression fits well with recent shifts in the positions of some leading right-wing populist politicians in several European countries, from mere Eurosceptic nationalism to pro-European stances with a right-wing twist. For instance, Hungary's Prime Minister Victor Orbán has adapted Trump's slogan, calling to "make Europe great again. " ${ }^{\prime 0}$ During Austria's recent election campaign, rightwing populist party FPÖ leader Heinz-Christian Strache praised the EU as a "positive project." ${ }^{.11}$ Most recently, Czech parliamentary election winner Andrej Babis surprisingly stated that his party, ANO, was pro-European and that he wants to take an active role in the EU to "fight against migration and other issues." 72 Although such a rhetorical shift cannot necessarily be observed in all leaders of the far right in Europe, the post-Trump increase in the EU's popularity among the parts of the population identifying as right-wing observed in this study ${ }^{73}$ could be part of a larger process of attempted usurpation of the EU through right-wing forces. Hence, instead of a rally-'round-the-flag effect, it would perhaps be more appropriate to speak of a conquer-the-flag effect, in which 
the right aims at reshaping Europe and the EU according to its ideas, that is, as a strong and closed fortress and inward-looking power that is fit enough to compete with Trump's America. While perhaps too suggestive of a unified and coordinated activity by the European right that did not exist to this extent at this point in time, this picture would fit the common perception of the right as more susceptible to external threats and zero-sum logics that require fierce deterrence and unitary responses. The stable, continuing high EU popularity scores among the center and the left, however, show that it is not clear whether the right would be successful in any such "takeover" attempt. Who will determine the EU's future political orientation is thus an open question and more research is needed to confirm this shift in the EU's base of support and to determine its longevity. Future research should also go deeper in exploring the exact meaning European integration has for the right today.

The finding that the rise in the EU's popularity was also particularly high among respondents who perceived the economic situation of their home country as "very bad" could be interpreted as a positive sign for the legitimacy base of the EU. Among these respondents, initial EU popularity values were much lower than in any other group, but the Trump effect brought their views on the EU at least slightly closer to the more favorable ones among respondents who were less concerned about their countries' economy. This shows that said part of the European population is not "lost" for the EU but in fact susceptible to changing their opinion on European integration in response to news, in this case the external shock of Trump's surprise victory. Following Baum, at least parts of this group appear to be closer to the point of ambivalence between approval and disapproval rather than inveterate and fierce opponents of the EU. ${ }^{74}$

More generally, then, this study shows the complexity and partial unpredictability of political chains of interaction. A shift in one direction in one part of the world does not necessarily lead to a simple domino effect in the same direction in another part. This insight is important, because humans seem to have an inbuilt tendency to make unidirectional extrapolations. As shown in the discussion of a potential domino effect, such expectations of linearity were clearly visible in Europe after Trump's victory. ${ }^{75}$ Countervailing effects are much harder to foresee and reveal, and in this case a natural experiment helped uncover them. Furthermore, this study contributes to the growing literature on the impact of exceptional historical events on public support for integration in the field of EU studies. Many of the events studied in past research, such as the Euro and refugee crises, lasted several years. This study, by contrast, reveals the instant impact that a singular event can have from one day to the next on these ostensibly inert public opinion structures. While some historical changes are slow and long term, in other instances "history, in fact, is a very sudden thing." 76

This study is not without limitations. For one thing, the Eurobarometer is relatively short on sociodemographic variables. Although controlling for more covariates is not necessary given the experimental setup of the study, additional individual-level information, such as a well-constructed social-class variable, would have been useful. A more important limitation is that it was only possible to examine the short-term Trump effect. Whether this effect persists in the long run and whether politicians will be able to transform it into political capital that may ultimately lead to a deepening-or, more generally, a reshaping - of European integration can only be speculated about. Yet even if additional survey material became available in the future, a long-term effect would be hard to prove causally due to the many intervening events. ${ }^{77}$

A further concern regards the normative evaluation of this shift. In the first half of the twentieth century, Hannah Arendt warned that the unifying effects that arise from a perceived external threat are not necessarily desirable forces. She concluded that "Americanism on one side and Europeanism on the other side of the Atlantic, two ideologies facing, fighting, and, above all, resembling each other as all seemingly opposing ideologies do- this may be one of the dangers we face." ${ }^{78}$ Care must be taken, therefore, not to glorify the positive Trump effect on the EU's popularity as a victory for cosmopolitan forces in response to a parochialist threat.

\section{Notes}

1 Five Thirty Eight 2016.

2 Roberts et al. 2016; Steltzner 2016.

3 Tolentino 2016.

4 Arkin 2015.

5 Reilly 2016.

6 Timm 2015.

7 European Parliament 2016; Krastev 2017, 6; Maher 2016; Quest 2016.

8 Boomgaarden and Vreese 2007, 354.

9 Silver 2017, emphasis added.

10 Jakobsson and Blom 2014; Legewie 2013.

11 Depetris-Chauvín and Durante 2017.

12 Hoffman and Bearman 2015.

13 Czymara and Schmidt-Catran 2017.

14 Donohue, Aneja, and Weber 2017.

15 Ferwerda and Miller 2014.

16 Bhavnani 2009.

17 E.g., Inglehart, Rabier, and Reif 1987.

18 E.g., Kuhn et al. 2016.

19 Smetko et al. 2003; Elenbaas et al. 2012.

20 De Vries 2018.

21 Ibid.

22 Degner 2017; Hobolt and Wratil 2015; Kuhn and Stöckel 2014. 
23 Harteveld, Schaper, and De Lange 2018.

24 Hobolt 2016.

25 Foos and Bischof 2018.

26 Cf. King, Keohane, and Verba 1994.

27 Mueller 1970.

28 Arian and Olzaeker 1999; Kazun 2016; Lai and Reiter 2005; Perrin and Smolek 2009.

29 Deutsch et al. 1957, 156-157.

30 McCarthy 2016.

31 European Parliament 2016; Krastev 2017, 6; Maher 2016; Quest 2016.

32 Farrell 2017.

33 Arendt 1994, 416.

34 Ibid, 416.

35 Baum 2002.

36 Colaresi 2007.

37 Baker and Oneal 2001.

38 Stone 2017.

39 Leeson and Dean 2009.

40 Baldwin 1993.

41 Hobolt 2016; Stone 2017.

42 Mudde 2016; see also Kirkegaard 2017.

43 Wellings 2010, 2014; Vasilopoulou 2011; Halikiopoulou, Nanou, and Vasilopoulou 2012.

44 Grabow and Hartleb 2013; Van Elsas and van der Brug 2015.

45 Bremmer 2017; Kirkegaard 2017; Silver 2017.

46 The online appendix contains several additional subgroup analyses, based on political sophistication (i.e., knowledge about the EU) and a split of the EU into East and West as well as North and South. Furthermore, it presents robustness checks for the two main subgroup analyses presented here, with national unemployment rate and change in unemployment rate as two alternative (and more "objective," country-level) indicators for the economic situation of the country (cf. Braun and Tausendpfund 2014) and territorial identification and globalization-related ideology (based on Teney, Lacewell, and De Wilde 2014) as alternative indicators for political orientation.

47 Van Elsas and van der Brug 2015.

48 Rubin 1974.

49 Holland 1986.

50 Dunning 2012.

51 See the online appendix, items 2 and 3.

52 Dunning 2012, 121.

53 See the online appendix, item 11.

54 Roberts et al. 2016.

55 Steltzner 2016.

56 If, however, this unlikely anticipation of Trump's win did appear, the estimates in this research are conservative rather than invalid. In the event that Europeans were anticipating Trump's win, and given that this anticipation affects the EU's popularity levels, they would probably already be higher or lower than average four days prior to the election, making the gap to the post-election EU popularity values smaller than it would be otherwise.

57 Finseraas, Jakobsson, and Kotsadam 2011; Finseraas and Listhaug 2013; Legewie 2013.

58 The reasons for creating this index rather than drawing on a single item are twofold. On the one hand, our goal was to capture the multifaceted nature of an abstract concept like the EU's popularity, and research suggests using an "overinclusive" item pool in such cases; Clark and Watson 1995. On the other hand, the standard item that is often used to measure EU support ("Do you think membership of the EU is a good thing/ a bad thing/ neither good nor bad") was only available for EU candidate countries and Cyprus TCC in this particular Eurobarometer. However, a robustness check, where we additionally use a single item that measures trust in the EU, confirms our results (see the online appendix, item 9).

59 Comrey and Lee 1992.

60 E.g., Rodriguez 2014.

61 Angrist and Pischke 2008.

62 Ibid.

63 Ibid.

64 Finseraas, Jakobsson, and Kotsadam 2011; Finseraas and Listhaug 2013; Legewie 2013; see also Gelman and Hill 2007, 213-214.

65 E.g., Hooghe and Marks 2005; Inglehart, Rabier, and Reif 1987; Kuhn et al. 2016; Lubbers and Scheepers 2010.

66 E.g., Kuhn 2012; Hakhverdian et al. 2013.

67 See the online appendix, item 5.

68 This shift mirrors findings from other studies showing that the political support base for regional integration may change over time, for instance in Latin America; Deutschmann and Minkus 2018.

69 See the online appendix, item 5.

70 Eder 2017.

71 Bartlau 2017.

72 Muller 2017.

73 In the online appendix, item 5, we reconfirm this effect using two additional indicators, showing that the Trump effect on the EU's popularity is largest among communitarians (as opposed to cosmopolitans) and among those identifying exclusively with their nation (as opposed to those having an at least partly European identity).

74 Baum 2002.

75 E.g., Mudde 2016; Kirkegaard 2017.

76 Philip Roth, cited in Krastev 2017, 35.

77 See the discussion of Silver 2017 in the opening of this article.

78 Arendt 1994, 417. 


\section{Supplementary Material}

Robustness Checks

1. Placebo analysis

2. Balancing the sample by excluding older respondents

3. Testing the effect of imbalances between countries in fieldwork distribution

4. Prosperity score matching and nearest neighbor matching

5. Testing alternative measures for the subgroup analyses

6. Are political orientation or territorial identification not exogenous?

7. Does political sophistication mediate the Trump effect?

8. Is there an East/West or a South/North divide?

9. Using a standard single item as DV

10. Could the Trump effect actually be a general "U.S. presidential election effect"?

11. Could the Trump effect actually be an effect caused by other events?

12. Replicating the Trump effect with another survey

13. Did people become more chauvinistic or more cosmopolitan post-Trump?

To view supplementary material for this article, please visit https://doi.org/10.1017/S1537592718003262.

\section{References}

Angrist, Joshua D. and Jörn-Steffen Pischke. 2008. Mostly Harmless Econometrics: An Empiricist's Companion.

Princeton, NJ: Princeton University Press.

Arendt, Hannah. 1994 [1930-1954]. Essays in

Understanding, 1930-1954. New York: Schocken Books.

Arian, Asher and Sigalit Olzaeker. 1999. "Political and

Economic Interactions with National Security

Opinion: The Gulf War Period in Israel." Journal of

Conflict Resolution 43(1): 58-77.

Arkin, Daniel. 2015. "Donald Trump Criticized after He Appears to Mock Reporter Serge Kovaleski." NBC

News, November 26. Available at https://www. nbcnews.com/politics/2016-election/new-york-timesslams-donald-trump-after-he-appears-mock-n470016; accessed September 14, 2017.

Baker, William D. and John R. Oneal. 2001. "Patriotism or Opinion Leadership? The Nature and Origins of the "Rally 'round the Flag' Effect." Journal of Conflict Resolution 45(5): 661-87.

Baldwin, Richard. 1993. "A Domino Theory of Regionalism.” Working Paper No. 4465. Cambridge, MA: National Bureau of Economic Research.

Bartlau, Christian. 2017. "Merkel muss keine Angst vor Kurz haben [Merkel does not need to fear Kurz]." ntv. Available at https://www.n-tv.de/politik/Merkel-musskeine-Angst-vor-Kurz-haben-article20092040.html; accessed October 25, 2017.
Baum, Matthew A. 2002. "The Constituent Foundations of the Rally-Round-the-Flag Phenomenon."

International Studies Quarterly 46(2): 263-98.

Bhavnani, Rikhil. 2009. "Do Electoral Quotas Work After They Are Withdrawn? Evidence from a Natural Experiment in India." American Political Science Review 103(1): 23-35.

Boomgaarden, Hajo G. and Claes H. de Vreese. 2007. "Dramatic Real-World Events and Public Opinion Dynamics: Media Coverage and Its Impact on Public Reactions to an Assassination." International Journal of Public Opinion Research 19(3): 354-66.

Braun, Daniela and Markus Tausendpfund. 2014. "The Impact of the Euro Crisis on Citizens' Support for the European Union." Journal of European Integration 36(3): 231-45.

Bremmer, Ian. 2017. "2017 Might Not Be Europe's 'Year of the Populist' After All.” Time. Available http://time. com/4688223/european-union-populism-netherlandselection/; accessed September 11, 2017.

Clark, Lee Anna and David Watson. 1995. "Constructing Validity: Basic Issues in Objective Scale Development." Psychological Assessment 7(3): 309-19.

Colaresi, Michael. 2007. "The Benefit of the Doubt: Testing an Informational Theory of the Rally Effect." International Organization 61(1): 99-143.

Comrey, Andrew L. and Howard B. Lee. 1992. A First Course in Factor Analysis. 2d ed. Hillsdale, NJ: Erlbaum.

Czymara, Christian S. and Alexander W. Schmidt-Catran. 2017. "Refugees Unwelcome? Changes in the Public Acceptance of Immigrants and Refugees in Germany in the Course of Europe's Immigration Crisis." European Sociological Review 33(6): 735-51.

Degner, Hanno. 2017. "Public Attention, Governmental Bargaining, and Supranational Activism: Explaining European Integration in Response to Crises." Journal of Common Market Studies. Available at https://doi.org/ $10.1111 / \mathrm{jcms} .12686$.

Depetris-Chauvín, Emilio and Ruben Durante. 2017. "One Team, One Nation: Football, Ethnic Identity, and Conflict in Africa." CEPR Discussion Paper DP12233. Available at https://papers.ssrn.com/sol3/ papers.cfm?abstract_id=3028599.

Deutsch, Karl, Sidney Burrell, Robert Kann, Maurice Lee Jr., Martin Lichterman, Raymond Lindgren, Francis Loewenheim, and Richard Van Wagenen. 1957. Political Community and the North Atlantic Area. Princeton, NJ: Princeton University Press.

Deutschmann, Emanuel and Lara Minkus. 2018.

"Swinging Leftwards: Public Opinion on Economic and Political Integration in Latin America, 1997-2010." Latin American Research Review 53(1): $38-56$. 
De Vries, Catherine. 2018. Euroscepticism and the Future of European Integration. Oxford: Oxford University Press.

Donohue, John, Abhay Aneja, and Kyle D. Weber. 2017. "Right-to-Carry Laws and Violent Crime: A Comprehensive Assessment Using Panel Data and a State-Level Synthetic Controls Analysis." NBER Working Paper 23510.

Dunning, Thad. 2012. Natural Experiments in the Social Sciences: A Design-Based Approach. Cambridge, UK: Cambridge University Press.

Eder, Florian. 2017. "Viktor Orbán: Make Europe (But Not the EU) Great Again." Politico. Available at https:// www.politico.eu/article/viktor-orban-make-europebut-not-the-eu-great-again/; accessed October 25, 2017.

Ellenbaas, Matthijs, Claes H. De Vreese, Hajo G. Boomgaarden, and Andreas R. T. Schuck. 2012. "The Impact of Information Acquisition on EU Performance Judgments." European Journal of Political Research 51(6): 728-55.

European Parliament, ed. 2016. "US Elections: 'We Are Not Very Sure What Exactly Trump's Foreign Policy Agenda Is'." Available at bit.ly/2yBnDI7, accessed September 12, /2017.

Farrell, Henry. 2017. "Thanks to Trump, Germany Says It Can't Rely on the United States. What Does That Mean?" Available at https://www.washingtonpost.com/ news/monkey-cage/wp/2017/05/28/thanks-to-trumpgermany-says-it-cant-rely-on-america-what-does-thatmean $/$ ? noredirect $=$ on\&utm_term $=.267116636 \mathrm{e} 4 \mathrm{~b}$; last accessed May 12, 2018.

Ferwerda, Jeremy and Nicholas Miller. 2014. "Political Devolution and Resistance to Foreign Rule: A Natural Experiment." American Political Science Review 108(3): 642-60.

Finseraas, Henning, Niklas Jakobsson, and Andreas Kotsadam. 2011. "Did the Murder of Theo van Gogh Change Europeans' Immigration Policy Preferences?" Kyklos 64(3): 396-409.

Finseraas, Henning and Ola Listhaug. 2013. "It Can Happen Here: The Impact of the Mumbai Terror Attacks on Public Opinion in Western Europe." Public Choice 156(1-2): 213-28.

FiveThirtyEight. 2016. "National Polls." Available at https://projects.fivethirtyeight.com/2016-electionforecast/national-polls/; accessed September 8, 2017.

Foos, Florian and Daniel Bishof. 2018. "Can the Tabloid Media Create Eurosceptic Attitudes? A Quasiexperiment on Media Influence in England." Available at http://www.florianfoos.net/resources/Foos_ Bischof_Hillsborough.pdf; accessed April 10, 2018.

Gelman, Andrew and Jennifer Hill. 2007. Data Analysis Using Regression and Multilevel/Hierarchical Models. Vol. 1. New York: Cambridge University Press.
Grabow, Karsten and Florian Hartleb. 2013. Europa - nein danke? Studie zum Aufstieg rechts- und nationalpopulistischer Parteien in Europa [Europe - No Thanks? A Study on the Rise of Right-wing and Nationalist Populist Parties in Europe]. Berlin: Konrad Adenauer Foundation.

Hakhverdian, Armen, Erika Van Elsas, Wouter Van der Brug, and Theresa Kuhn. 2013. "Euroscepticism and Education: A Longitudinal Study of 12 EU Member States, 1973-2010.” European Union Politics 14(4): 522-41.

Halikiopoulou, Daphne, Kyriaki Nanou, and Sofia Vasilopoulou. 2012. "The Paradox of Nationalism: The Common Denominator of Radical Right and Radical Left Euroscepticism." European Journal of Political Research 51(4): 504-39.

Harteveld, Eelco, Joep Schaper, and Sarah L. De Lange. 2018. "Blaming Brussels? The Impact of (News about) the Refugee Crisis on Attitudes towards the EU and National Politics." Journal of Common Market Studies 56(1): 157-77.

Hobolt, Sara B. 2016. "The Brexit Vote: A Divided Nation, A Divided Continent." Journal of European Public Policy 23(9): 1259-77.

Hobolt, Sara B. and Christopher Wratil. 2015. "Public Opinion and the Crisis: The Dynamics of Support for the Euro. Journal of European Public Policy 22(2): $238-56$.

Hoffman, Mark A. and Peter S. Bearman. 2015. "Bringing Anomie Back In: Exceptional Events and Excess Suicide." Sociological Science 2: 186-210.

Holland, Paul W. 1986. "Statistics and Causal Inference." Journal of the American Statistical Association 81(396): 945-60.

Hooghe, Liesbet and Gary Marks. 2005. "Calculation, Community and Cues: Public Opinion on European Integration." European Union Politics 6(4): 419-43.

Inglehart, Ronald, Jacques-René Rabier, and Karlheinz Reif. 1987. "The Evolution of Public Attitudes toward European Integration: 1970-1986." Journal of European Integration 10(2-3): 135-55.

Jakobsson, Niklas and Svein Blom. 2014. "Did the 2011 Terror Attacks in Norway Change Citizens' Attitudes Toward Immigrants?" International Journal of Public Opinion Research 26(4): 475-86.

Kazun, Anastasia. 2016. "Framing Sanctions in the Russian Media: The Rally Effect and Putin's Enduring Popularity." Demokratizatsiya 24(3): 327-50.

King, Gary, Robert O. Keohane, and Sidney Verba.1994. Designing Social Inquiry. Princeton, NJ: Princeton University Press.

Kirkegaard, Jacob. 2017. "Fears of Right-Wing Populism May Be Overblown in Europe." Peterson Institute for 
International Economics. Available at https://piie.com/ blogs/realtime-economic-issues-watch/fears-rightwing-populism-may-be-overblown-europe; accessed September 12, 2017.

Krastev, Ivan. 2017. After Europe. Philadelphia: University of Pennsylvania Press.

Kuhn, Theresa. 2012. "Why Educational Exchange Programmes Miss Their Mark: Cross-border Mobility, Education and European Identity." Journal of Common Market Studies 50(6): 994-1010.

Kuhn, Theresa, Erika van Elsas, Armen Hakhverdian, and Wouter van der Brug. 2016. "An Ever Wider Gap in an Ever Closer Union: Rising Inequalities and Euroscepticism in 12 West European Democracies, 1976-2008." Socio-Economic Review 14(1): 27-35.

Kuhn, Theresa and Florian Stoeckel. 2014. "When European Integration Becomes Costly: The Euro Crisis and Public Support for European Economic Governance." Journal of European Public Policy 21(4): 624-41.

Lai, Brian and Dan Reiter. 2005. "Rally' round the Union Jack? Public Opinion and the Use of Force in the United Kingdom, 1948-2001." International Studies Quarterly 49(2): 255-72.

Leeson, Peter T. and Andrea M. Dean. 2009. "The Democratic Domino Theory: An Empirical Investigation." American Journal of Political Science 53(3): 533-51.

Legewie, Joshua. 2013. "Terrorist Events and Attitudes toward Immigrants: A Natural Experiment." American Journal of Sociology 118(5): 1199-245.

Lubbers, Marcel and Peer Scheepers. 2010. "Divergent Trends of Euroscepticism in Countries and Regions of the European Union." European Journal of Political Research 49(6): 787-817.

Maher, Richard. 2016. "European Leaders Would See a Donald Trump Victory as Total Calamity." Huffington Post. Available at https://www.huffingtonpost.com/ the-conversation-global/european-leaders-wouldse_b_12745308.html; accessed October 12, 2017.

McCarthy, Niall. 2016. "Europeans Are Terrified by the Prospect of Trump Becoming President." Forbes. Available at: https://www.forbes.com/sites/niallmccarthy/ 2016/11/04/europeans-are-terrified-by-the-prospect-oftrump-becoming-president-infographic/\#52ee7b7d262f; accessed October 12, 2017.

Mudde, Cas. 2016. "Europe's Far Right Has Been Boosted by Trump's Win-For Now." November 9, 2016. The Guardian. Available at https://www. theguardian.com/commentisfree/2016/nov/09/ donald-trump-win-europe-far-right-norbert-hofermarine-le-pen; accessed September 12, 2017.

Mueller, John E. 1970. "Presidential Popularity from Truman to Johnson." American Political Science Review 64(1): 18-34. Muller, Robert. 2017. "Czech Vote Winner Babis Wants Active EU Role, Not Favoring Government with
Extremists." Reuters. Available at https://www.reuters. com/article/us-czech-election-babis/czech-vote-winnerbabis-wants-active-eu-role-not-favoring-governmentwith-extremists-idUSKBN1CQ0U8; accessed October 25, 2017.

Perrin, Andrew J. and Sondra J. Smolek. 2009. "Who Trusts? Race, Gender, and the September 11 Rally Effect among Young Adults." Social Science Research 38(1): 134-45.

Quest, Richard. 2016. “Trump's Challenge: Will He Help Hold the European Union Together?" CNN. Available at https://edition.cnn.com/2016/11/09/politics/ donald-trump-europe-global-headaches/index.html; accessed September 12, 2017.

Reilly, Katie. 2016. "Here Are All the Times Donald Trump Insulted Mexico." Time, August 31. Available at http://time.com/4473972/donald-trump-mexicomeeting-insult/; accessed September 13, 2017.

Roberts, Dan, Sabrina Siddiqui, Ben Jacobs, Lauren Gambino, and Amanda Holpuch. 2016. "Donald Trump Wins Presidential Election, Plunging US into Uncertain Future." The Guardian. Available at https:// www.theguardian.com/us-news/2016/nov/09/donaldtrump-wins-us-election-news; accessed September 13, 2017.

Rodriguez, Robert G. 2014. "Reassessing the Rise of the Latin American Left." Midsouth Political Science Review 15(1): 53-80.

Rubin, Donald B. 1974. "Estimating Causal Effects of Treatments in Randomized and Nonrandomized Studies." Journal of Educational Psychology 66(5): 688-701.

Silver, Nate. 2017. "Donald Trump Is Making Europe Liberal Again.” June 14. Available at https://fivethirtyeight.com/features/donald-trump-is-making-europeliberal-again/; accessed September 12, 2017.

Smetko, Holli A., Wouter van der Brug, and Patti M. Valkenburg. 2003. "The Influence of Political Events on Attitudes Towards the European Union." British Journal of Political Science 33(4): 621-34.

Steltzner, Holger. 2016. "Herausforderung Trump. [Challenge Trump]" Frankfurter Allgemeine. Available at http://www.faz.net/aktuell/wirtschaft/wirtschaftspolitik/ kommentar-herausforderung-trump-14520777.html; accessed September 12, 2017.

Stone, Jon. 2017. "More Europeans Than Ever Say They Feel Like Citizens of the EU." August 2, 2017. Independent. Available at https://www.independent.co. $\mathrm{uk} /$ news/uk/politics/eu-brexit-european-union-citizens-feel-like-eurobarometer-survey-results-a7872916. html; accessed September 12, 2017.

Teney, Céline, Onawa Promise Lacewell, and Pieter De Wilde. 2014. "Winners and Losers of Globalization in Europe: Attitudes and Ideologies." European Political Science Review 6(4): 575-95. 
Timm, Jane C. 2015. "Trump Calls for Discrimination Against Muslims." MSNBC, December 7. Available at http://www.msnbc.com/msnbc/trump-callsdiscrimination-against-muslims; accessed September 11, 2017.

Tolentino, Jia. 2016. "Donald Trump's Unconscious, Unending Sexism." The New Yorker, October 10. Available at https://www.newyorker.com/culture/ jia-tolentino/donald-trumps-unconscious-unendingsexism; accessed September 14, 2017.

Van Elsas, Erika and Wouter van der Brug. 2015. "The Changing Relationship between Left-right Ideology and Euroscepticism, 1973-2010." European Union Politics 16(2): 194-215.
Vasilopoulou, Sofia. 2011. "European Integration and the Radical Right: Three Patterns of Opposition."

Government and Opposition 46(2): 223-44.

Wellings, Ben. 2010. "Losing the Peace: Euroscepticism and the Foundations of Contemporary English Nationalism." Nations and Nationalism 16(3): 488-505.

$$
\text { 2014. "English Nationalism and }
$$

Euroscepticism OVERLAP and Support Each Other in Important Ways." LSE British Politics and Policy Blog. Available at http://blogs.lse.ac.uk/ politicsandpolicy/english-nationalism-andeuroscepticism/; accessed April 20, 2018.

Table A1

Subgroup analysis by perceived economic situation of the country; DV: EU popularity index.

\begin{tabular}{|c|c|c|c|c|c|c|c|c|}
\hline \multirow{4}{*}{$\begin{array}{l}\text { Treatment group }(1=\text { yes }) \\
\text { Female }(1=\text { yes }) \\
\text { Age }\end{array}$} & \multicolumn{2}{|c|}{ Very bad } & \multicolumn{2}{|c|}{ Rather bad } & \multicolumn{2}{|c|}{ Rather good } & \multicolumn{2}{|c|}{ Very good } \\
\hline & $0.095^{\star}$ & $(0.05)$ & 0.007 & $(0.02)$ & 0.006 & $(0.02)$ & 0.076 & $(0.08)$ \\
\hline & 0.008 & $(0.05)$ & 0.044 & $(0.02)$ & $0.064^{* *}$ & $(0.02)$ & -0.011 & $(0.08)$ \\
\hline & $-0.006^{\star \star}$ & $(0.00)$ & $-0.004^{\star \star \star}$ & $(0.00)$ & $-0.005^{\star \star \star}$ & $(0.00)$ & -0.001 & $(0.00)$ \\
\hline Occupation & & & & & & & & \\
\hline White collar & (ref) & & (ref) & & (ref) & & (ref) & \\
\hline Self-employed & 0.000 & $(0.10)$ & 0.005 & $(0.05)$ & -0.076 & $(0.05)$ & -0.025 & $(0.14)$ \\
\hline Manual & -0.044 & $(0.08)$ & $-0.079^{\star}$ & $(0.03)$ & -0.042 & $(0.03)$ & -0.198 & $(0.13)$ \\
\hline Homemaker & -0.115 & $(0.11)$ & -0.069 & $(0.06)$ & -0.045 & $(0.05)$ & 0. & $(0.20)$ \\
\hline Unemployed & $-0.342^{\star \star \star}$ & $(0.09)$ & $-0.226^{\star \star \star}$ & $(0.05)$ & $-0.142^{*}$ & $(0.06)$ & -0.068 & $(0.23)$ \\
\hline Retired & 0.009 & $(0.09)$ & -0.035 & $(0$. & -0.021 & $(0$. & 0. & $(0.13)$ \\
\hline Student & $0.516^{\star}$ & $(0.21)$ & $0.435^{\star \star *}$ & $(0.09)$ & 0.140 & $(0.08)$ & 0.284 & $(0.27)$ \\
\hline $\operatorname{Urban}(=1,0=$ rural $)$ & -0.033 & $(0.05)$ & $0.058^{*}$ & $(0.03)$ & $0.111^{\star \star *}$ & $(0.02)$ & -0.042 & $(0.09)$ \\
\hline Education (in years) & $0.019^{\star \star}$ & $(0.01)$ & $0.014^{\star \star *}$ & $(0.00)$ & 0.003 & $(0.00)$ & 0.011 & $(0.01)$ \\
\hline Country dummies & & & $\checkmark$ & & $\checkmark$ & & & \\
\hline Constan & -0.068 & $(0.21)$ & 0.135 & $(0.11)$ & $0.667^{\star \star \star}$ & $(0.11)$ & 0.520 & $(0.31)$ \\
\hline $\begin{array}{l}\text { Observations } \\
R^{2}\end{array}$ & $\begin{array}{l}2,287 \\
0.19\end{array}$ & & $\begin{array}{l}6,510 \\
0,14\end{array}$ & & $\begin{array}{c}6,572 \\
0,14\end{array}$ & & $\begin{array}{l}750 \\
0.16\end{array}$ & \\
\hline
\end{tabular}

Note: Treatment group: Interviewed after November 9.

Robust standard errors in parentheses.

Own calculations, based on Eurobarometer 86.2, not weighted.

${ }^{*} p<0.05,{ }^{* *} p<0.01,{ }^{* * *} p<0.001$. 


\section{Table A2}

Subgroup analysis by partisanship; DV: EU popularity index.

\begin{tabular}{|c|c|c|c|c|c|c|}
\hline \multirow[b]{2}{*}{ Treatment group ( $1=$ yes) } & \multicolumn{2}{|c|}{ Left } & \multicolumn{2}{|c|}{ Center } & \multicolumn{2}{|c|}{ Right } \\
\hline & 0.007 & $(0.03)$ & 0.032 & $(0.03)$ & $0.114^{\star \star}$ & $(0.04)$ \\
\hline Female $(1=$ yes $)$ & 0.053 & (0.03) & -0.013 & (0.02) & $0.077^{*}$ & $(0.04)$ \\
\hline Age & $-0.004^{\star \star}$ & $(0.00)$ & $-0.004^{\star \star \star}$ & $(0.00)$ & -0.003 & $(0.00)$ \\
\hline Occupation & & & & & & \\
\hline White collar & (ref) & & (ref) & & (ref) & \\
\hline Self-employed & -0.117 & $(0.06)$ & -0.046 & $(0.05)$ & -0.076 & $(0.06)$ \\
\hline Manual & $-0.154^{\star \star \star}$ & $(0.04)$ & $-0.091^{\star}$ & $(0.04)$ & -0.002 & $(0.05)$ \\
\hline Homemaker & $-0.215^{\star \star}$ & $(0.08)$ & -0.063 & $(0.06)$ & -0.090 & $(0.10)$ \\
\hline Unemployed & $-0.388^{* \star *}$ & (0.07) & $-0.164^{\star *}$ & (0.06) & $-0.355^{\star \star \star}$ & (0.08) \\
\hline Retired & $-0.105^{\star}$ & $(0.05)$ & -0.031 & (0.04) & 0.013 & (0.06) \\
\hline Student & $0.471^{\star \star *}$ & $(0.11)$ & $0.442^{\star \star \star}$ & (0.10) & 0.210 & $(0.14)$ \\
\hline Urban $(=1,0=$ rural $)$ & $0.074^{*}$ & (0.03) & 0.045 & $(0.03)$ & $0.096^{\star \star}$ & $(0.04)$ \\
\hline Education (in years) & $0.019^{\star \star \star}$ & $(0.00)$ & $0.013^{\star \star \star}$ & (0.00) & 0.003 & $(0.00)$ \\
\hline Country dummies & $\checkmark$ & & $\checkmark$ & & $\checkmark$ & \\
\hline Constant & 0.114 & $(0.13)$ & $0.245^{\star}$ & $(0.11)$ & 0.261 & $(0.16)$ \\
\hline $\begin{array}{l}\text { Observations } \\
R^{2}\end{array}$ & $\begin{array}{l}4,321 \\
0.18\end{array}$ & & $\begin{array}{l}6,134 \\
0.13\end{array}$ & & $\begin{array}{l}3,695 \\
0.16\end{array}$ & \\
\hline
\end{tabular}

Note: Treatment group: Interviewed after November 9.

Robust standard errors in parentheses.

Own calculations, based on Eurobarometer 86.2, not weighted.

${ }^{*} p<0.05,{ }^{* *} p<0.01,{ }^{* * *} p<0.001$. 